\title{
Effect of Handling by Human Being Neonatal Period on Anxiety and Depression-Like Behavior of Adult Rats
}

\author{
Amir Manseur*, Abdelmajid Bairi, Amira Bakeche, Amina Djouini, Abdelkrim Tahraoui \\ Applied Neuroendocrinology Laboratory, Department of Biology, Faculty of Science, University Badji Mokbtar BP12 \\ 23000, Annaba, Algeria.
}

\begin{abstract}
Human-animal interactions occur in many sectors of livestock production. This study aims to determine whether human manipulation during the critical period could disrupt their long-term behavior. Forty-four pup rats (22 males and 22 females), were divided into two groups (handling, non-handling: corresponding to the control group). Subsequently, each group was subdivided into two subgroups: male subgroup (Handling Males, $\mathrm{H}^{\Uparrow}$ ) and a female subgroup (Handling Female, $\mathrm{H}$ + ), which were handled daily for $5 \mathrm{~min}$ from birth to weaning. On postnatal days (PND 67,70,73), they were subjected to three behavioral tests respectively: open field (OF), elevated plus-maze (EPM) and forced swim test (FST). Within the open field, the results showed that in both sexes, the manipulated group had spent less time in corners, more time in the center, had more squares crossed and finally, more rearing. The results also showed significantly lower levels of anxiety, which translates into more time spent in open arms of the elevated plus-maze. Improved adaptation to depression was observed in forced swimming tests as they had more swimming time and less immobility time. Therefore, human handling during the neonatal period of rats could induce greater resistance to depression and better adaptation to anxiety without any negative effects on behavior.
\end{abstract}

Keywords | Anxiety, Behavior, Depression, Neonatal handling, Rats

Received | July 31, 2019; Accepted | November 12, 2019; Published | November 26, 2019

*Correspondence | Amir Manseur, Applied Neuroendocrinology Laboratory, Department of Biology, Faculty of Science, University Badji Mokhtar BP12 23000, Annaba, Algeria; Email: manseur_amir@hotmail.fr

Citation | Manseur A, Bairi A, Bakeche A, Djouini A, Tahraoui A (2019). Effect of handling by human being neonatal period on anxiety and depression-like behavior of adult rats. Adv. Anim. Vet. Sci. 7(12): 1113-1119.

DOI | http://dx.doi.org/10.17582/journal.aavs/2019/7.12.1113.1119

ISSN (Online) | 2307-8316; ISSN (Print) | 2309-3331

Copyright (C) 2019 Manseur et al. This is an open access article distributed under the Creative Commons Attribution License, which permits unrestricted use, distribution, and reproduction in any medium, provided the original work is properly cited.

\section{INTRODUCTION}

$\mathrm{S}_{\mathrm{b}}^{\mathrm{e}}$ everal studies have focused on the therapeutic and beneficial effects of animals on humans, but not on the effects of humans on animal welfare, although animal welfare is now a major concern in modern society. In recent years, interest in studying the human-animal relationship in domestic species has increased, particularly for economic reasons. Poor quality of this relationship can have negative consequences on animal production and reproduction performance, such as a decrease in milk production in cattle (Bertenshaw and Rowlinsona, 2015), and goats (Lyons, 1989), and a decrease in the reproductive capacity of pigs (Hemsworth et al., 1981; Hemsworth et al., 1989). In addition, to a stress reaction that results in a reduced growth rate in young pigs (Hemsworth et al., 1981), there is a decrease in fertility in sows, and a reduction in testicle size in boars (Hemsworth et al., 1986).

The brain of the offspring after birth is very sensitive to environmental factors, epigenetic mechanisms that play a central role in the long-term, even transgenerational (Gressens and Mezger, 2014) . Thus, studies on neonatal environmental effects and their interactions on behavior and stress adaptation are of paramount importance to better understand the impact of the early environment effect on the behavioral and cognitive development of adult animals.

In recent years, several studies have investigated the effects of neonatal stress on behavior and stress resistance in animal and human models, and have found that prenatal stress can affect the emotional and cognitive ability of rat pups (Cabrera et al., 1999; Nishio et al., 2001), in addition 
to causing adult-specific alterations in response to aversive situations (Cabib et al., 1993), such as psychosis, behavioral disorders, depressive syndromes, addictive disorders and memory disorders with disruption of the functional maturation of hippocampal networks (Parker, 1981; Holmes and Robbins, 1987; Canetti et al., 1997; Benoit et al., 2015; Reincke and Hanganu-Opatz, 2017).

Furthermore, rhesus monkeys raised in an enriched neonatal environment, have superior performance in orientation and motor activity, with fewer temperamental responses (such as fear) compared to rhesus raised in a less rich environment (Schneider et al., 1991; Bard et al., 2001). Tremblay (2002) suggested that some types of maternal care improve spatial learning and memory of the offspring by increasing hippocampal development.

Human-animal interactions are sometimes very close and are mainly done through non-verbal language. Indeed, the main element of communication that allows the creation of a relationship between human and animal is physical contact or touch (Servais, 2007). Thus, this study aims to determine the effects of long-term human neonatal physical manipulation on anxiety, locomotion, and depressive behavior of adult rats.

\section{MATERIALS AND METHODS}

\section{Animals}

Forty-four albino weaned rats ( 22 males and 22 females) of Wistar strain obtained from mating six males and six females rats of the same strain were used during experimentation phase. They were provided by the Pasteur Institute in Algiers, Algeria. The rats were housed in polycarbonates cages in a colony room of the Department of Biology, University of Annaba, Algeria, and reared under standard laboratory conditions (temperature of 25 $\pm 2{ }^{\circ} \mathrm{C}$, humidity $50 \pm 5 \%$, artificial lighting, $12 \mathrm{~h}$ light/ $12 \mathrm{~h}$ night from 07h00). They were fed on standard rat chow produced by ONAB (national office of animal feed manufacturing), Annaba, Algeria, and supplied with water ad libitum.

\section{EXPERIMENTAL DESign}

All experimental procedures described in this work were carried out in accordance with the guide for the care and use of laboratory animals of the University of Badji Mokhtar Annaba,Algeria.Figure 1 presents the experimental design.

For the synchronization of estrous cycles in female rats, six males and six females of the same strain were placed in a compartmentalized cage without physical contact for 7 days, which allowed exposure to male pheromones. Males and females were then placed in cages for reproduction. Vaginal smears were examined daily for sperm presence.
The males were then removed and the pregnant females were reared in individual cages until parturition.

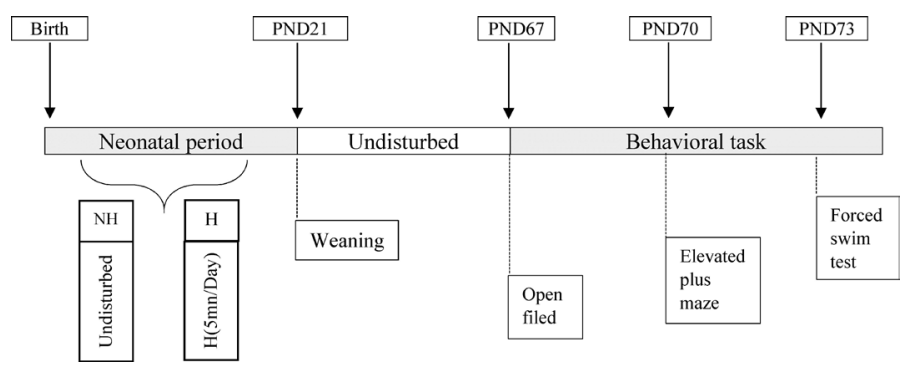

Figure 1: Diagram and Timeline of the Experimental design. $\mathrm{H}$ : handling. $\mathrm{NH}$ : non-handling. $\mathrm{NH}$ group was left undisturbed. H group was exposed to daily handling session for $5 \mathrm{~min}$ from birth till weaning. At postnatal day (PND) 67 began performing the following behavioral tasks at 10:00am - 12:00pm: open field test (OF) on PND67, elevated plus-maze test (EPM) on PND70 and forced swim test (FST) on PND73.

Birth day was noted PND 0, and the offspring remained with their mothers were separated into two experimental groups: handling $(\mathrm{H})$, and non-handling group $(\mathrm{NH})$. The offspring of the $(\mathrm{H})$ group were physically manipulated by the experimenter for 5 min per day till PND 21 (weaning), while, the $\mathrm{NH}$ group had no physical manipulation.

After weaning, the offspring were separated from their mothers, 11 males and 11 females were randomly selected from each group $(\mathrm{NH}=22, \mathrm{H}=22 ; 11 \delta / 11$ ㅇ $)$ and raised in pairs in each cage to adulthood under the standard conditions mentioned above. In PND 67, they were subjected to behavioral tests to assess anxiety level, locomotor behavior, exploratory behavior and depressive behavior.

\section{Handling (physical manipulation)}

The physical manipulation of the offspring was carried out according to touching method described by Weininger (1954), Therefore, the animal is held in the experimenter's left hand and placed against the experimenter's chest, so that the animal is nestled in the palm of the left hand, and with the thumb or fingers, the experimenter caresses the animal's back from head to the base of the tail. The offspring were handled individually, 5 min per day from PND1 to PND21 at 9.00 am by the same experimenter. A thin layer of sawdust was collected from the nest and deposited in the palm of hand to avoid any emotional stress of a new environment.

\section{BEHAVIORAL TESTS}

The behavioral tests were conducted at 48-hour intervals between each test to avoid any interference with the subsequent test result in the following order: open field test (OF) at PND 67, elevated plus-maze (EPM) at PND 70, 
and forced swim test at PND73. All tests were performed in a quiet room, after $20 \mathrm{~min}$ of habituation to the test room during the lighting period (between 10:00 am and 12:00 pm). After the behavior assessment, the rats were returned to their breeding room.

\section{Open FIELD (OF)}

The open field test (OF) consisted of a square-shaped floor with a white background $(70 \mathrm{~cm} \mathrm{x} 70 \mathrm{~cm})$, divided by black lines into 49 squares of equal size $(10 \mathrm{~cm} \times 10$ $\mathrm{cm}): 24$ peripheral squares and 25 in the center. The floor was surrounded by $30 \mathrm{~cm}$ high transparent Plexiglas walls. Twenty minutes before the start of the test, the rats were moved to the test room to get used to it. The rat was placed in the center and its behavior was recorded for $5 \mathrm{~min}$ by a video camera. The device was cleaned with $10 \%$ ethanol after each rat. This test was used to evaluate locomotor activity by counting the number of squares crossed, the number of rearing and exploratory behavior by calculating the time spent in the periphery compared to the time spent in the center (Hall, 1934).

\section{Elevated Plus-Maze (EPM)}

The EPM test is a well-known device for testing anxiety in laboratory rodents. It consists of two opened arms $(50 \mathrm{~cm} \mathrm{x}$ $10 \mathrm{~cm})$ crossed at right angles to two closed arms $(50 \mathrm{~cm} \times 10$ $\mathrm{cm}$, surrounded by $40 \mathrm{~cm}$ high walls). The device was raised $50 \mathrm{~cm}$ above the ground. The rat was placed in the center facing one of the opened arms and behavior was recorded for $5 \mathrm{~min}$ by a video camera. The device was cleaned with $10 \%$ ethanol after each rat. The number of rearing, entries in opened and closed arms and time spent in opened and closed arms were estimated (Pellow et al., 1985).

\section{ForCED SWIMMING TEST (FST)}

The Forced Swimming Test (Porsolt swimming test) was used to examine the depressive behavior of rats (Porsolt et al., 1977). The device consisted of an aquarium (54 x $38 \times$ $40 \mathrm{~cm}$ ) filled with water at $25{ }^{\circ} \mathrm{C}$ up to $30 \mathrm{~cm}$ height. At this height, the rat cannot use its lower limbs to stay at the surface and is therefore subjected to forced swimming.

The water temperature was maintained at $25^{\circ} \mathrm{C}$ using an electric immersion heater before the beginning of each session. The FST was conducted in two sessions, the pretest and the test, separated by a 24 -hour interval. During the pre-test, the rat was placed for $15 \mathrm{~min}$ in the aquarium filled with water in which it could not escape, to create a mental depression (depressed session). On the test day, the rat was plunged back into the aquarium for a 5-min session during which immobility, swimming and climbing time was recorded as an indicator of depressive behavior.

\section{STATISTICAL ANALYSIS}

Student's T-test was used to determine the difference between groups during behavioral tests using Addinsoft XLSTAT-Premium, version 2016. The results were presented as a mean \pm SEM. Multivariate analysis (MANOVA) Lambda Wilk's test was used to analyze the intragroup sex-effect on rat behavior by IBM SPSS Statistics 23.0. At $\mathrm{p}<0.05$, the difference was considered significant.

\section{RESULTS}

\section{OPEN FIELD TEST}

Figure 2 illustrates the exploratory and locomotor performance of rats in the open field test. The panels A, B, $\mathrm{C}$ and $\mathrm{D}$ (Figure 2) revealed a greater increase in locomotor and exploratory behavior of the handled rats, compared to the non-handled group for both sexes, with a decrease in time spent in corners $[\widehat{\partial}: \mathrm{t}=3.17, \mathrm{p}=0.006, \mathrm{~F}=0.25$; + $: \mathrm{t}=$ $3.32, \mathrm{p}=0.003, \mathrm{~F}=0.28]$, increase in time spent in center $[\widehat{o}: \mathrm{t}=-3.17, \mathrm{p}=0.006, \mathrm{~F}=0.25 ; \mathrm{q}: \mathrm{t}=-3.10, \mathrm{p}=0.006, \mathrm{~F}$ $=0.30]$, increase in number of squares crossed $[\widehat{O}: \mathrm{t}=-3.98$, $\mathrm{p}=0.0007, \mathrm{~F}=2.54 ; \%: \mathrm{t}=-2.81, \mathrm{p}=0.01, \mathrm{~F}=1.51]$ and an increased rearing number $\left[\delta^{\lambda}: \mathrm{t}=-3.85, \mathrm{p}=0.002, \mathrm{~F}=\right.$ $0.25 ;$; $: \mathrm{t}=-2.84, \mathrm{p}=0.01, \mathrm{~F}=1.43]$ respectively in panels.
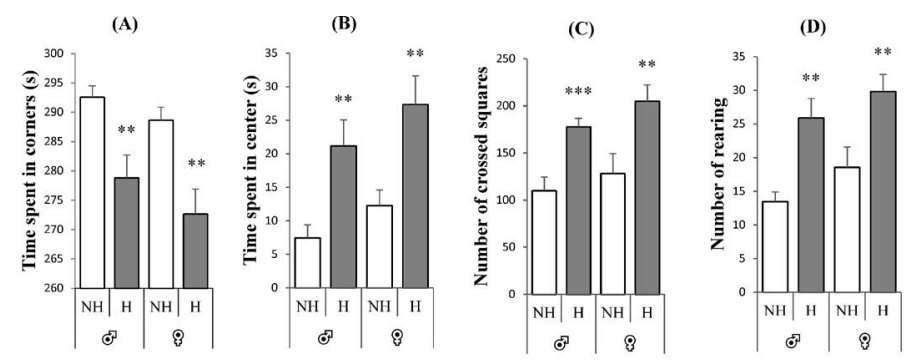

Figure 2: Effect of neonatal handling on the open field behaviors of rats of both sexes. A: time in seconds spent in corners, B: time in seconds spent in center, $\mathrm{C}$ : number of crossed squares and D: number of rearing. Expressed as mean \pm SEM. NH: non-handling, H: handling. ${ }^{* *} \mathrm{p}<0.01$, $* * * * 0.001$

\section{Elevated Plus-Maze (EPM)}

Figure 3 illustrates the anxiety level of rats of both sexes in the EPM. Panel B (Figure 3) revealed a decreased anxiety behavior in the handled group, compared to the non-handled group, showed by an increase in time spent in opened arms for both sexes $[\widehat{\delta}: \mathrm{t}=-3.22, \mathrm{p}=0.004, \mathrm{~F}=$ $0.37 ; \circ: t=-3.28, p=0.004, F=2.03]$. However, an increase in the number of entries in the opened arms $[\delta: t=-5.71$, $\mathrm{p}=0.0001, \mathrm{~F}=1.72]$ and number of rearing $\left[\mathrm{o}^{\lambda}: \mathrm{t}=-4.88\right.$, $\mathrm{p}=0.0001, \mathrm{~F}=0.84]$ (Panels D and E), was observed only in male handled rats, compared to female handled rats [o+: $\mathrm{t}=-1.74, \mathrm{p}=0.098, \mathrm{~F}=3.43]$ (Panel D), $[0$ : $\mathrm{t}=-1.70, \mathrm{p}=$ $0.11, \mathrm{~F}=2.56]$ (Panel E). While, no significant differences were observed for the other parameters, for both sexes: time spent in closed arms in panel A $[\hat{\delta}: \mathrm{t}=1.28, \mathrm{p}=0.22$, $\mathrm{F}=0.94 ;$; $: \mathrm{t}=1.13, \mathrm{p}=0.28, \mathrm{~F}=3.99]$ and number of 
entries in the closed arms in panel $\mathrm{C}[\hat{O}: \mathrm{t}=-2.07, \mathrm{p}=$ $0.052, \mathrm{~F}=0.89 ;$; $: \mathrm{t}=-1.45, \mathrm{p}=0.16, \mathrm{~F}=1.40]$.
(A)

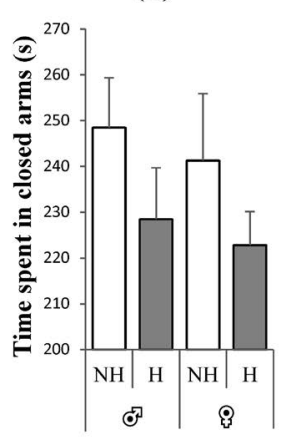

(B)

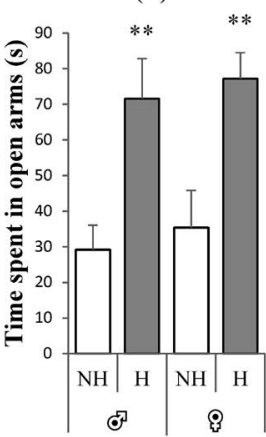

(D)

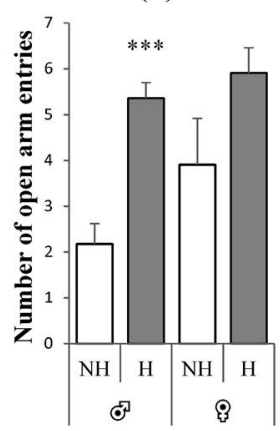

(C)

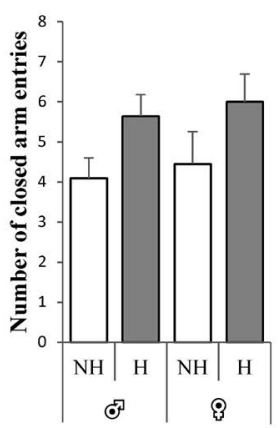

(E)

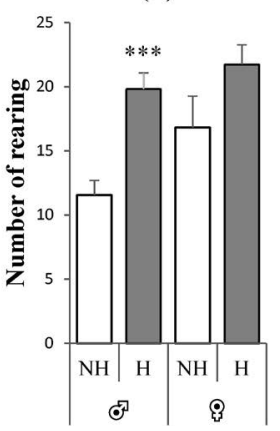

Figure 3: Effect of neonatal handling on the elevated plusmaze behaviors of rats of both sexes. A: time in seconds spent in closed arms, B: time in seconds spent in opened arms, C: number of closed arms entries, D: number of opened arms entries and E: number of rearing. Expressed as mean \pm SEM. NH: non-handling, H: handling. ${ }^{* *} \mathrm{p}<$ $0.01, * * * * 0.001$.
(A)

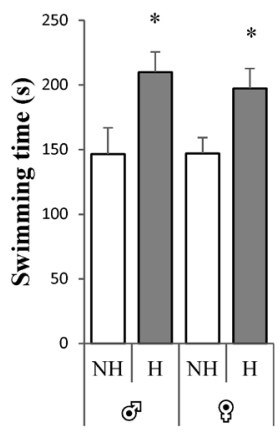

(B)

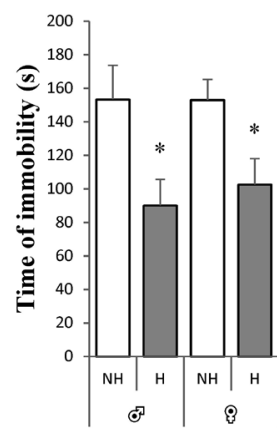

(C)

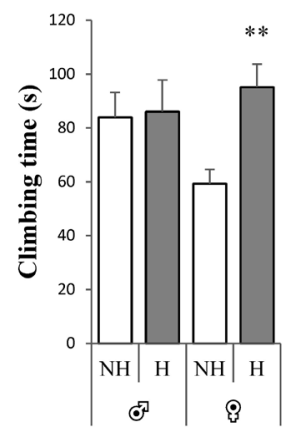

Figure 4: Effect of neonatal handling on the forced swimming test behaviors of rats of both sexes. A: swimming time in seconds, B: time of immobility and C: climbing time in seconds. Expressed as mean \pm SEM. NH: nonhandling, $\mathrm{H}$ : handling. ${ }^{*} \mathrm{p}<0.05,{ }^{* *} \mathrm{p}<0.01$.

\section{FORCED SWIMMING TEST (FST)}

Figure 4 illustrates the depressive behavior of rats of both sexes during the FST. The panels A and B revealed a greater reduction in depressive behavior of the handled rats, compared to the non-handled group, for both sexes with an increase in swimming time $[\hat{\sigma}: \mathrm{t}=-6.71, \mathrm{p}=0.0001, \mathrm{~F}$ $=1.77 ;$; $: \mathrm{t}=-6.35, \mathrm{p}=0.0001, \mathrm{~F}=1.27]$ and a decrease in time of immobility [ $\widehat{\jmath}: \mathrm{t}=6.71, \mathrm{p}=0.0001, \mathrm{~F}=1.77 ;$; $: \mathrm{t}$ $=6.35, \mathrm{p}=0.0001, \mathrm{~F}=1.27]$. Panel $\mathrm{C}$ revealed an increase in climbing time for female handled rats with very highly significant differences in comparison with non-handling female group [ $\mathrm{O}: \mathrm{t}=-3.58, \mathrm{p}=0.002, \mathrm{~F}=0.39$ ], however, no significant difference was observed for male handled rats $[\hat{O}: \mathrm{t}=0.66, \mathrm{p}=0.52, \mathrm{~F}=2.42]$.

\section{SEX EFFECT ON DIFFERENT PARAMETERS OF HANDLED} RATS

Table 1 shows that the sexual factor does not significantly affect the studied parameters of handled rats $[\mathrm{p}=0.437, \mathrm{~F}$ $(11,10)=1.17]$.

Table 1: Sex-dependent effect on the different parameters studied (Multivariate test: Lambda Wilk's test). H: handling group (Number of rats: 22 with 11 rats of each sexes). Value: the value of Wilk's Lambda. F: Fisherstatistic. df: degrees of freedom. Sig: significance ( $p$-value).

$\begin{array}{llllll}\text { H } & & & & & \\ \text { Effect } & \text { Value } & \text { F } & \text { Hypothesis df } & \text { Error df } & \text { Sig } \\ \text { Sex } & 0.437 & 1.17 & 11 & 10 & 0.406\end{array}$

\section{DISCUSSION}

The purpose of this study was to determine the extent to which human handling, applied from birth to weaning, modifies exploratory behavior, locomotor performance and resistance to depression in adult male and female rats, and thus verify whether human interaction during the neonatal period of rats has any impact in adulthood.

It is well known that in early development, central nervous system has a high plasticity and can be very sensitive to even moderate environmental interventions (Gschanes et al., 1998; Zhang and Cai, 2008), therefore, early life experiences have long-term effects on behavior and stress responsiveness (Padoin et al., 2001). Several studies have shown that distinct stimuli during the early life affect the behavioral, physiological and endocrine processes in adult rats (Casolini et al., 1997; Knuth and Etgen, 2007).

The results reported changes in the behavior of adult rats of both sexes, based on treatment applied during the neonatal period and indicated by reduced anxiety level and increased locomotor and exploratory behaviors.

The time spent in the center of the open field was higher in the handling group, which is a sign of less anxiety. In addition, the increase in distance traveled (i.e. number of crossed squares) in the open field suggested that locomotor activity was better developed in handled rats.

Similarly, exploratory behavior (measured as the number 
of rearing for vertical exploration and the time spent in the center and/or periphery for horizontal exploration) increased in the handling group compared to the nonhandling group. These results are consistent with previous studies indicating that early manipulation increases the threshold of emotional reactivity in rats as well as diminished fear of novelty (Bodnoff et al., 1987).

Indeed, it was also found that the anxiety level of adult rats of both sexes evaluated by the performance in EPM was significantly lower in handled rats compared to untreated ones. These results are in good agreement with previous studies suggesting that adequate neonatal manipulation during early life provides better responses of adults in new situations and environments (Fernandez-Teruel et al., 1990; Wakshlak and Weinstock, 1990; Vallée et al., 1997; Boufleur et al., 2012).

Moreover, swimming time was greatly increased by handling, and immobility time was reduced, which indicates a better adaptation to depression (Porsolt et al., 1977). Boufleur et al. (2012) observed that physical manipulation during the first days of life in rats has a protective effect and decreases the doses of an anxiolytic and antidepressant drugs as diazepam, in case such intervention is required.

Also, females climbing time was significantly higher than that of the males handled, which implies a greater escape intensity in females that could be evolutionarily significant. As potential mothers, females should become more familiar with the unknown environment than males, to ensure smooth progress in pregnancy, childbirth and offspring care (Dubovicky et al., 1999).

Neonatal handling is similar to maternal affection and licking (Schanberg and Field, 1987), and therefore, has a strong influence on normal brain development (Chiba et al., 2012). Tactile stimulation has been shown to affect the function of the hypothalamic-pituitary-adrenal axis (HPA) (Katsouli et al., 2014), enhance the adult's ability to adapt to stressful stimuli (Stamatakis et al., 2009), and assist in the recovery of neonatal brain injury (Rodrigues et al., 2004; Richards et al., 2012). Moreover, it has been shown that also postnatal handling in an early life experience could induce neuro-chemical, physical and psychological changes in the offspring. Thus, it allows greater psychological and physiological adaptation to stressed adults (Cirulli et al., 2003; Pryce and Feldon, 2003; Weaver et al., 2004; Imanaka et al., 2008), and to have a long-term effect on adult behavior (Giachino et al., 2007).

No specific sex effect results were observed in the handled group. These results are consistent with those of Imanaka et al. (2008), who reported no significant interaction between neonatal treatments and sex in the open field, elevated plus-maze and sensitivity to pain. In contrast, Rhees et al. (2001) reported that manipulated females were more active than males, this sex-related contradiction of results might be due to differences in experimental paradigms such as breeding environment, age of animals and handling period.

\section{CONCLUSION}

The purpose of this study was to determine whether human manipulation during the critical period could disrupt their long-term behavior. Forty-four small rats (22 males and 22 females) were divided into two groups (handling, nonhandling: corresponding to the control group).

The results showed the beneficial effects of neonatal handling on locomotion and exploratory behavior as well as an improved anxiety and depressive behavior.

Thus, it could be concluded that neonatal handling by humans can prevent behavioral disorders in adult rats. However, the mechanisms involved in this modification remain unknown and the data obtained by a behavioral test had limited relevance for understanding the origin of the neurobiological axis involved.

Therefore, further research is needed to clarify how the external environment during the neonatal period interacted with the neuroendocrine axis in adulthood. This is particularly important since the quality of the humananimal relationship and the behavior of the breeder are important factors to be taken into account in the different animal production systems due to their influence on the animal's productivity, health and welfare.

\section{AUTHORS CONTRIBUTION}

All authors contributed equally.

\section{CONFLICT OF INTEREST}

The authors declare that there is no conflict of interest.

\section{REFERENCES}

- Bard KA, Platzman K, Lester BM, Suomi SJ (2001). Neurobehavioral integrity and emotions in chimpanzee and human neonates. Enfance. 53: 226-235. https://doi. org/10.3917/enf.533.0226

-Benoit JD, Rakic P, Frick KM (2015). Prenatal stress induces spatial memory deficits and epigenetic changes in the hippocampus indicative of heterochromatin formation and reduced gene expression. Behav. Brain. Res. 0: 1-8. https:// doi.org/10.1016/j.bbr.2014.12.001

-Bertenshaw C, Rowlinsona P (2015). Exploring stock Managers' perceptions of the human-animal Relationship on dairy 
farms and an association with milk production. Anthrozoös. 22: 59-69. https://doi.org/10.2752/175303708X390473

-Bodnoff SR, Suranyi-Cadotte B, Quirion R, Meaney MJ (1987). Postnatal handling reduces novelty-induced fear and increases $3 \mathrm{H}$-flunitrazepam binding in rat brain. Eur. J. Pharmacol. 144: 105 - 107. https://doi.org/10.1016/00142999(87)90016-1

- Boufleur N, Antoniazzi CTD, Pase CS, Benvegnù DM, Barcelos RCS, Dolci GS, Dias VT, Roversi K, Roversi K, Koakoskia G, Rosa JG, Barcellos LJ, Bürger ME (2012). Neonatal tactile stimulation changes anxiety-like behavior and improves responsiveness of rats to diazepam. Brain. Res. 1474: 50 59. https://doi.org/10.1016/j.brainres.2012.08.002

- Cabib S, Puglisi-Allegra S, D'Amato FR (1993). Effects of postnatal stress on dopamine mesolimbic system responses to aversive experiences in adult life. Brain. Res. 604: 232 239. https://doi.org/10.1016/0006-8993(93)90374-V

- Cabrera RJ, Rodrîguez-Echandîa EL, Jatuff ASG, Fôscolo M (1999). Effects of prenatal exposure to a mild chronic variable stress on body weight, preweaning mortality and rat behavior. Braz. J. Med. Biol. Res. 32: 1229 - 1237. https:// doi.org/10.1590/S0100-879X1999001000009

- Canetti L, Bachar E, Galili-Weisstub E, De-Nour AK, Shalev AY (1997). Parental bonding and mental health in adolescence. Adolesc. 32: 381 - 394 .

- Casolini P, Cigliana G, Alem GS, Ruggieri V, Angelucci L, Catalani A (1997).Effect of increased maternal corticosterone during lactation on hippocampal corticosteroid receptors, stress response and learning offspring in the early stages of life. Neurosci. 79: 1005 - 1012. https://doi.org/10.1016/ S0306-4522(96)00668-9

- Chiba S, Numakawa T, Ninomiya M, Richards MC, Wakabayashi C, Kunugi H (2012). Chronic restraint stress causes anxiety and depression-like behaviors downregulates glucocorticoid receptor expression, and attenuates glutamate release induced by brain-derived neurotrophic factor in the prefrontal cortex. Prog. Neuro-Psychoph. 39: 112 - 119. https://doi.org/10.1016/j.pnpbp.2012.05.018

- Cirulli F, Berry A, Alleva E (2003). Early disruption of the mother-infant relationship: effects on brain plasticity and implications for psychopathology. Neurosci. Biobehav. R. 27: 73 - 82. https://doi.org/10.1016/S0149-7634(03)00010-1

-Dubovicky M, Skultetyova I, Jezova D (1999). Neonatal stress alters habituation of exploratory behavior in adult male but not female rats. Pharmacol. Biochem. Be. 64: 681 - 686 . https://doi.org/10.1016/S0091-3057(99)00166-5

-Fernandez-Teruel A, Escorihuela RM, Jimenez P, Tobena A (1990). Infantile stimulation and perinatal administration of Ro 15-1788: Additive anxiety-reducing effects in rats. Eur. J. Pharmacol. 191: 111 - 114. https://doi.org/10.1016/00142999(90)94104-6

- Giachino C, Canalia N, Capone F, Fasolo A, Alleva E, Riva MA, Cirulli F, Peretto P (2007). Maternal deprivation and early handling affect density of calcium binding proteincontaining neurons in selected brain regions and emotional behavior in periadolescent rats. Neurosci. 145: 568 - 578. https://doi. org/10.1016/j.neuroscience.2006.12.042

- Gressens P, Mezger V (2014). Le développement cérébral et l'environnement: périodes critiques [Brain development and the environment: critical periods]. In: Soins de développement en période néonatale [Development care in the neonatal period], J. Sizun, B. Guillois, C. Casper, G. Thiriez and P. Kuhn (eds), Springer, Paris,
FR, 2014, 1: 3 - 15. https://doi.org/10.1007/978-2-81780529-0_1

- Gschanes A, Eggenreich U, Windisch M, Crailsheim K (1998). Early postnatal stimulation influences passive avoidance behaviour of adult rats. Behav. Brain. Res. 93: 91 - 98. https://doi.org/10.1016/S0166-4328(97)00143-5

- Hall CS (1934). Emotional behavior in the rat: I. Defecation and urination as measures of individual differences in emotionality. J. Comp. Psychol. 18: 385 - 403. https://doi. org/10.1037/h0071444

-Hemsworth PH, Barnett JL, Coleman GJ, Hansen C (1989). A study of the relationships between the attitudinal and behavioural profiles of stock persons and the level of fear of humans and reproductive performance of commercial pigs. Appl. Anim. Behav. Sci. 23: 301 - 314. https://doi. org/10.1016/0168-1591(89)90099-3

-Hemsworth PH, Barnett JL, Hansen C (1986). The influence of handling by humans on the behavior reproduction and corticosteroids of male and female pigs. Appl. Anim. Behav. Sci. 15: 303 - 314. https://doi.org/10.1016/01681591(86)90123-1

-Hemsworth PH, Barnett JL, Hansenc (1981). The influence of handling by humans on the behavior, growth and corticosteroids in the juvenile female pig. Horm. Behav. 15: 396 - 403. https://doi.org/10.1016/0018-506X(81)90004-0

- Holmes SJ, Robbins LN (1987). The influence of childhood disciplinary experience on the development of alcoholism and depression.J. Child.Psychol.Psyc. 28: 399 - 415.https:// doi.org/10.1111/j.1469-7610.1987.tb01762.x

-Imanaka A, Morinobu S, Toki S, Yamamoto S, Matsuki A, Kozuru T, Yamawaki S (2008). Neonatal tactile stimulation reverses the effect of neonatal isolation on open-field and anxiety-like behavior, and pain sensitivity in male and female adult Sprague-Dawley rats. Behav. Brain. Res. 186: 91 - 97. https://doi.org/10.1016/j.bbr.2007.07.039

-Katsouli S, Stamatakis A, Giompres P, Kouvelas ED, Stylianopoulou F, Mitsacos A (2014). Sexually dimorphic long-term effects of an early life experience on ampa receptor subunit expression in rat brain. Neurosci. 257: $49-$ 64. https://doi.org/10.1016/j.neuroscience.2013.10.073

-Knuth ED, Etgen AM (2007). Long-term behavioral consequences of brief, repeated neonatal isolation. Brain. Res. 1128: 139 - 47.

- Lyons DM (1989). Individual differences in temperament of dairy goats and the inhibition of milk ejection. Appl. Anim. Behav. Sci. 22: 269 - 282. https://doi.org/10.1016/01681591(89)90022-1

- Nishio H, Kasuga S, Ushijima M, Harada Y (2001). Prenatal stress and postnatal development of neonatal rats sexdependent effects on emotional behavior and learning ability of neonatal rats. Int. J. Dev. Neurosci. 19: 37 - 45. https:// doi.org/10.1016/S0736-5748(00)00070-8

- Padoin MJ, Cadore LP, Gomes CM, Barros HMT, Lucion AB (2001). Long-lasting effects of neonatal stimulation on the behavior of rats. Behav. Neurosci. 115: 1332 - 1340. https:// doi.org/10.1037//0735-7044.115.6.1332

- Parker G (1981). Parental representations of patients with anxiety neurosis. Acta. Psychiat. Scand. 63: 33 - 36. https:// doi.org/10.1111/j.1600-0447.1981.tb00647.x

-Pellow S, Chopin P, File SE, Briley M (1985). Validation of open closed arm entries in an elevated plus-maze as a measure of anxiety in the rat. J. Neurosci. Meth. 14: 149 - 167. https://doi.org/10.1016/0165-0270(85)90031-7 
- Porsolt RD, Le Pinchon M, Jalfre M (1977). Depression: new animal model sensitive to antidepressant treatments. Nature. 266: 730 - 732. https://doi.org/10.1038/266730a0

- Pryce CR, Feldon J (2003). Long-term neurobehavioural impact of the postnatal environment in rats: manipulations, effects and mediating mechanisms. Neurosci. Biobehav. R. 27: 57 71. https://doi.org/10.1016/S0149-7634(03)00009-5

- Reincke SAJ, Hanganu-Opatz IL (2017). Early-life stress impairs recognition memory and perturbs the functional maturation of prefrontal hippocampal-perirhinal networks. Sci. Rep. UK. 7: 1 - 16. https://doi.org/10.1038/srep42042

- Rhees RW, Lephart ED, Eliason D (2001). Effects of maternal separation during early postnatal development on male sexual behavior and female reproductive function. Behav. Brain. Res. 123: 1 - 10. https://doi.org/10.1016/S01664328(00)00381-8

- Richards S, Mychasiuk R, Kolb B, Gibb R (2012). Tactile stimulation during development alters behaviour and neuroanatomical organization of normal rats. Behav. Brain. Res.231: 86 - 91. https://doi.org/10.1016/j.bbr.2012.02.043

- Rodrigues AL, Arteni NS, Abel C, Zylbersztejna D, Chazana R, Viola G, Xavier L, Achaval M, Netto CA (2004). Tactile stimulation and maternal separation prevent hippocampal damage in rats submitted to neonatal hypoxia-ischemia. Brain. Res. 1002: 94 - 99. https://doi.org/10.1016/j. brainres.2003.12.020

- Schanberg SM, Field TM (1987). Sensory deprivation stress and supplemental stimulation in the rat pup and preterm neonate. Child. Dev. 58: 1431 - 1447. https://doi. org/10.1111/j.1467-8624.1987.tb03856.x

- Schneider ML, Moore CF, Suomi SJ, Champoux M (1991). Laboratory assessment of temperament and environmental enrichment in rhesus monkey infants Macaca mulatta. Am. J. Primatol. 25: 137 - 155. https://doi.org/10.1002/ ajp. 1350250302
-Servais V (2007). La relation homme-animal. La relation à l'animal peut-elle devenir significative, donc thérapeutique, dans le traitement des maladies psychiques? Enfances Psy. 35: 46 - 57. https://doi.org/10.3917/ep.035.0046

-Stamatakis A, Toutountzi E, Fragioudaki K, Kouvelas ED, Stylianopoulou F, Mitsacos A (2009). Selective effects of neonatal handling on rat brain n-methyl-d-aspartate receptors. Neurosci. 164: 1457 - 1467. https://doi. org/10.1016/j.neuroscience.2009.09.032

- Tremblay RE (2002). Mothering matters: How rat pups benefit from a high level of maternal care. Bull. Early Child. Dev. 1: 10 .

-Vallée M, Mayo W, Dellu F, Le Moal M, Simon H, Maccari S (1997). Prenatal stress induces high anxiety and postnatal handling induces low anxiety in adult offspring: correlation with stress-induced corticosterone secretion. J. Neurosci. 17: 2626 - 2636. https://doi.org/10.1523/ JNEUROSCI.17-07-02626.1997

-Wakshlak A, Weinstock M (1990). Neonatal handling reverses behavioral abnormalities induced in rats by prenatal stress. Physiol. Behav. 48: 289 -292.https://doi.org/10.1016/00319384(90)90315-U

- Weaver ICG, Cervoni N, Champagne FA, D'Alessio AC, Sharma S, Seckl JR (2004). Epigenetic programming by maternal behavior. Nat. Neurosci. 7: 847 - 854. https://doi. org/10.1038/nn1276

-Weininger O (1954). Physiological damage under emotional stress as a function of early experience. Science. 119: 285 286. https://doi.org/10.1126/science.119.3087.285

-Zhang M, Cai JX (2008). Neonatal tactile stimulation enhances spatial working memory, prefrontal long-term potentiation, and D1 receptor activation in adult rats. Neurobiol. Learn. Mem. 89: 397 - 406. https://doi.org/10.1016/j. nlm.2007.10.010 